\title{
Massive cuts to science and medicine in Trump budget
}

\author{
— Cite as: CMAJ 2017 June 12;189:E812-3. doi: 10.1503/cmaj.1095437
}

T he budget proposed by United States President Donald Trump calls for "massive cuts" to spending on medical and scientific research, public health and disease-prevention programs, and health insurance for lowincome Americans and their children. It has drawn intense criticism from many corners, including scientists, physicians and politicians from both the Democratic and Republican parties. The only good thing about this "horror" of a budget, according to one pundit, is that it will likely get "eviscerated in Congress."

Under the proposed budget, formally delivered to Congress yesterday, the National Institutes of Health (NIH) would see its annual budget shrink $18 \%$ from $\$ 31.8$ billion to $\$ 26$ billion. This includes cuts to the National Cancer Institute (\$1 billion), National Heart, Lung and Blood Institute (\$575 million), and the National Institute of Allergy and Infectious Diseases ( $\$ 838$ million).

The Centers for Disease Control and Prevention (CDC) would lose $17 \%$ of its budget, a cut of $\$ 1.2$ billion. This news prompted former CDC Director Dr. Tom Frieden to take to Twitter and rebuke this "assault on science" that will "devastate" programs that protect Americans from many deadly conditions, including diabetes, heart attacks and strokes. He noted that the cuts would give the CDC its lowest budget in 20 years and lead to an increase in illness and deaths.

Others cuts include $\$ 776$ million to the National Science Foundation, a funder of scientific research, and a $31 \%$ reduction in funding for the Environmental Protection Agency (EPA), which includes a \$129-million cut to the enforcement of programs that support clean air and water. According to Erik Olson, director of public health for the Natural Resources

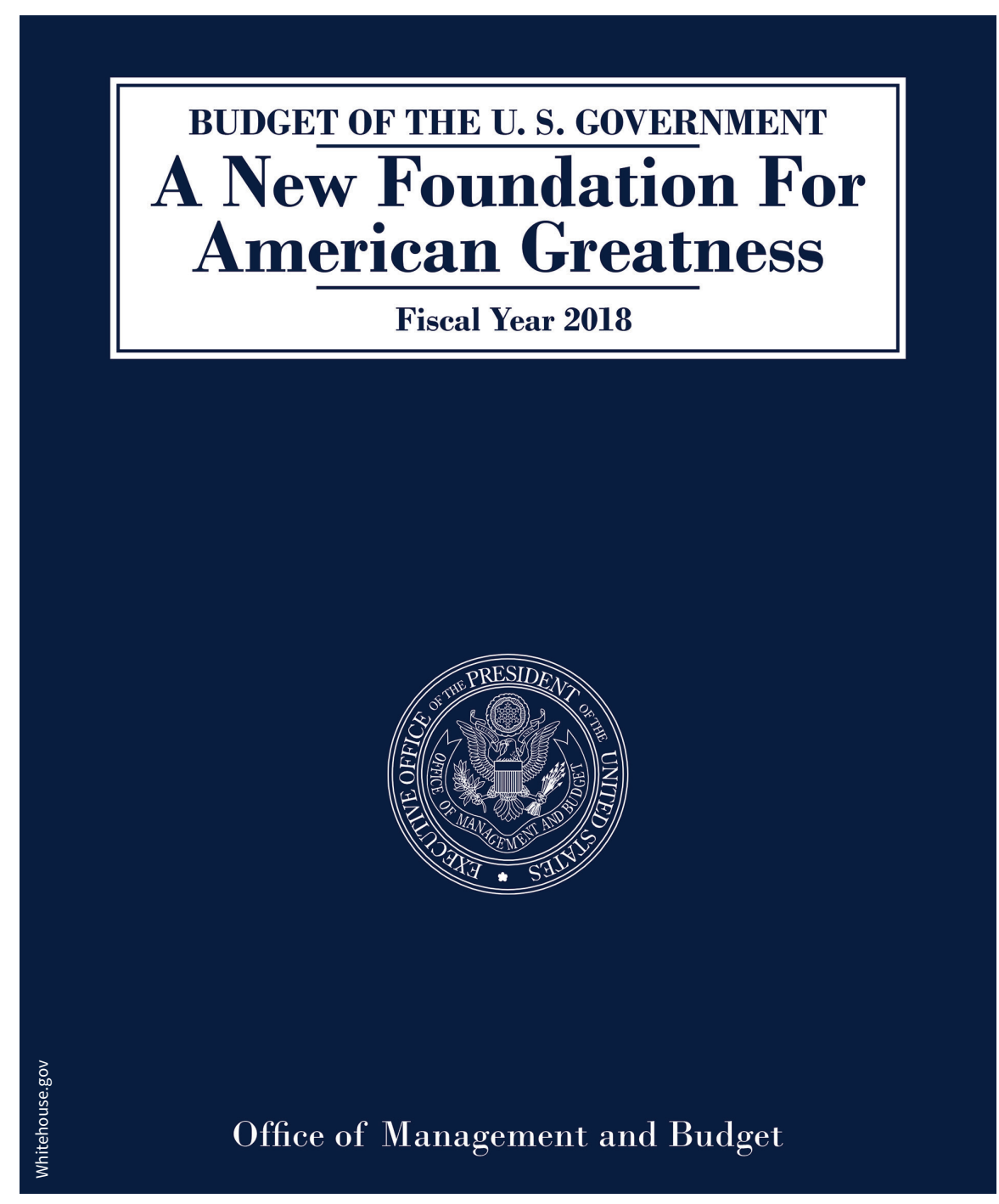

Deep cuts to science and medicine in Trump budget draw intense criticism.

Defense Council, the proposed cuts would be a "machete chop to most of the major body parts at EPA" and would directly affect public health.

There has been particular scorn heaped on the budget's plan to cut $\$ 610$ billion over 10 years from the Medicaid program, which provides health insurance to 74 million low-income Americans. This would be in addition to the $\$ 880$-billion cut already suggested in the Republican's health care plan. These reductions would see Medicaid's budget drop by nearly half by 2027 .

One senator referred to the Medicaid cuts as "just cruel." Even some Republicans balked at the Medicaid cuts suggested in Trump's budget. One Republican said he drew the line at proposed cuts to 
the popular Meals on Wheels program. The Republican chair of the House Appropriations Committee called the cuts to Medicaid "draconian." A Princeton professor who is an analyst for CNN said the Medicaid cuts would be devastating to the elderly, disabled and low-income adults and their children, and that Trump was picking the wrong health care battle by targeting a program that has become "a centerpiece of the US social safety net."

Other commentators and politicians have referred to the cuts proposed in Trump's budget as terrible, frightening, hostile to scientific innovation and innovation, stunning in cruelty and comicbook-villain bad, heartless, illogical and "so cruel a Russian propaganda outfit set the White House straight."
Vermont Senator Bernie Sanders called the budget immoral and said it would cause enormous pain to the most vulnerable Americans, adding that it "will be rejected by the American People and must not see the light of day here in Congress."

Despite the backlash from so many parties, the Trump administration is standing by the sweeping cuts proposed in the budget. Trump's budget chief, Mick Mulvaney, said many of the programs targeted for cuts are inefficient and a burden to taxpayers, adding that the government is "no longer going to measure compassion by the number of programs or the number of people on those programs, but the number of people we help get off of those programs."

Cuts to specific programs in the budget include:
- $\$ 333$ million to CDC programs to fight infectious diseases,

- \$136 million to CDC Office of Public Health Preparedness and Response,

- $\$ 76.3$ million to CDC Center for Global Health,

- \$3.7 billion to NIH funding for researchers,

- Elimination of the Fogarty International Center, which trains scientists and clinicians to work in developing countries,

- \$874 million to the Department of Energy's Office of Science,

- \$193 billion over 10 years to Supplemental Nutrition Assistance Program (food stamps) and

- \$5.8 billion to Children's Health Insurance Program over two years.

Roger Collier, CMAJ 